\title{
THE RELATIONSHIP BETWEEN STOCKS AND EXCHANGE RATES: AN ANALYSIS FROM LEHMAN BROTHERS COLLAPSE IN THE USA
}

\author{
HİSSE SENETLERİ VE DÖVIZ KURLARI ARASINDAKİ İLIŞKİ: \\ BİRLEŞİK DEVLETLER'DEKİ LEHMAN BROTHERS'IN ÇÖKÜSÜ \\ ÜZERINE BİR ANALIZ
}

\author{
Oğuzhan ERCAN ${ }^{*}$ iD \\ Jale S. ORAN ${ }^{* *}$ iD
}

\begin{abstract}
In this study, we comparatively examine the issue of granger causality between exchange rates and stock index for the United States before and after the global financial crisis within the context of Lehman Brothers' collapse. The analysis includes the monthly stock index and exchange rate data. Euro and Swiss Franc parities against Dollar were selected as exchange rates. After the investigation, we found out that Dow Jones Industrial Average and USD/CHF were the Granger cause of USD/EUR exchange rate before the collapse of Lehman Brothers. However, there is no causality after the collapse.

Keywords: Stock prices, exchange rates, granger causality test, johansen co-integration test, financial crisis JEL Classification: F31, G01, G15

Öz

Çalışma küresel finansal kriz öncesi ve sonrası Amerika Birleşik Devletleri için döviz kurları ile hisse senedi endeksi arasındaki granger nedensellik konusunu Lehman Brothers’ın çöküşü kapsamında karşılaştırmalı olarak incelemektedir. Analiz, aylık hisse senedi endeksi ve döviz kuru verilerini içerir. Döviz kuru olarak Dolar karşısındaki Euro ve İsviçre Frangı pariteleri seçilmiştir. Analizin ardından, Dow Jones Industrial Average ve USD/CHF’nin, Lehman Brothers'in çöküşünden önceki USD/EUR döviz kurunun Granger nedeni olduğu ortaya çıkmıştır. Ancak, Lehman Brothers’in çöküşünden sonra nedensellik ortadan kalkmaktadır.
\end{abstract}

* Sorumlu Yazar: Ph.D. Candidate in Accounting and Finance Department of Marmara University, oguzhan.ercan.94@ hotmail.com, ORCID: 0000-0003-4046-7054.

** Prof. Dr., Marmara University, Faculty of Business Administration, jaleoran@marmara.edu.tr, ORCID: 0000-0001-8976-2893.

To cite this article: Ercan, O. \& Oran, J. S. (2021). The relationship between stocks and exchange rates: An analysis from Lehman Brothers collapse in the USA. Journal of Research in Business, 6(2), 442-453.

"There is no requirement of Ethics Committee Approval for this study." 
Anahtar Kelimeler: Hisse senedi fiyatları, döviz kuru, granger nedensellik test, johansen eşbütünleşme testi, finansal kriz

JEL Sinıflandırması: F31, G01, G15

\section{Introduction}

In recent years, the importance of studies on the relationship between exchange rates and stock prices has increased in money and capital markets. There are several reasons why the linkage between foreign exchange rates and stock returns are significant. First, in relation to the economic crisis, it affects both monetary and fiscal policy decisions. Secondly, many investors diversify their assets between stock markets and foreign exchange markets in order to reduce investment risk. Hence, a proper estimation of the relationship between foreign exchange rates and stock returns is useful in investment decisions.

Stock returns are used as key indicators of real economic activity. Increasing returns on stocks are likely to be associated with increased investment in companies and expansion. Foreign exchange rates are also one of the key factors affecting the economy.

In this paper, the relationship between stock market prices and exchange rates was examined. It is not unusual to find studies with contradictory results regarding these two variables, due to different methodologies or different period data. Therefore, it is expected that this study will add to literature and support the body of knowledge in this respect.

The aim of this study is to examine Dow Jones Industrial Average Index and its relationship with the foreign exchange rates (Dollar / Euro and Dollar / Swiss Franc) in the United States of America between November 1999 to August 2008 and September 2008 to November 2019 separately, before and after the collapse of Lehman Brothers. In the next section, previous work is examined briefly. Third section presents data and highlights of empirical methodology that is employed in this study. Also, the empirical results are shown in this section. Last part, focuses on summary and conclusion.

\section{Literature Review}

A significant number of studies have been employed to predict the relationship between stock prices and exchange rates in various countries and regions for several decades. Empirical studies produced different results due to differences in time intervals, selected variables, regions and countries. Literature review is divided into two parts regarding the countries' economic advancement: Developed vs. developing countries. The first category would concentrate on studies that examined the relationship between exchange rates and stock indexes in the United States and developed countries as follows:

Aggarwal (1981) performed one of the first research on this topic and analyzed the relationship between exchange rates and U.S. stock market indices using monthly for the period 1974-1978. 
The empirical results showed a significant and positive relationship between stock returns and the exchange rates of dollar.

Ajayi \& Mougoue (1996) used daily data between 1985 and 1991 to investigate the relationship between exchange rates and stock indices for eight advanced nations (United States, United Kingdom, Netherlands, Italy, Japan, Germany, France and Canada). According to study results, rising stock returns has negative short term effects as well as positive long term impact on the currency value. National currency depreciation also has a negative effect on the stock market, both short and long term.

Nieh \& Lee (2001) analyzed the relationship between stock prices and exchange rates for G-7 countries and took stock market indices and foreign exchange rates from 1993 to 1996 on a daily basis. It is concluded that there is no long term relationship between exchange rates and stock returns for all nations that investigated.

Kim (2003) used monthly time index between 1974 and 1998 in the United States of America, and the empirical results revealed that the stock returns of S\&P 500 has a negative linkage to the exchange rate.

Stavarek (2005) conducted a study about the short and long run relationship between exchange rates and stock prices in the four EU member states, the Visegrad Four, the United States. In the research, monthly data were used for the analysis. After the investigation and implementation of causality tests, he reached that there is stronger relationship between stocks and exchange rates in the developed countries than other countries. Moreover, he also found that short and long run causality was stronger in integrated capital markets and later time periods. Consequently, if capital controls is repealed, the interaction between stock returns and exchange rates will become powerful.

Vygodina (2006) searched empirically the exchange rates and stock returns for large-cap and smallcap stocks in the United States from 1987 to 2005 and used Granger causality methodology. The study showed that from large-cap stocks to the exchange rate, Granger causality exists. On the other hand, for small cap stock returns, there is no causality.

Inci \& Lee (2014) also investigated the causality of exchange rates and stock prices in advanced countries. The selected countries were Italy, Switzerland, United Kingdom, Germany, France, Canada, United States and Japan. They found that lagged exchange rates effect stock prices significantly and there was a Granger causality from stock returns and exchange rates, and vice versa.

The second category of studies that examine the relationship between stock returns and exchange rates in developing nations are presented below.

Granger et al. (2000) analyzed the relationship between exchange rates and stock prices in nine Asian countries. It showed that there is a bivariate casuality between these variables in Malaysia, Hong Kong, Taiwan, Tailand and Sinagapore. 
Ajayi, Freidman \& Mehdian (1998) used exchange rates and daily stock market indexes to examine casual relationships between changes in exchange rates and stock returns for seven developed nations, for the period from 1985 to 1991, and eight emerging markets in Asia between 1987 and 1991. They used Granger causality test to examine the relationship. The results indicated that in all advanced economies there is a unidirectional causality between stock returns and exchange rates, whereas in emerging countries there are no significant causal relationships.

Muhammad \& Rasheed (2002) used monthly data from 1994 to 2000 to analyze exchange rates and stock price relationships for India, Pakistan, Sri Lanka and Bangladesh. The empirical results showed that only Bangladesh and Sri Lanka have a bi-directional long-term causality between these variables. They also found that there is no link for Pakistani and Indian markets between exchange rates and stock prices.

Doong et al. (2005) chose the weekly data to investigate the relationship between stock prices and exchange rates in Indonesia, Philippines, South Korea, Taiwan, Thailand and Malaysia. They used the data between 1989 and 2003. According to the research results, financial variables are not cointegrated. The analysis of the Granger causality test showed that for Korea, Indonesia, Thailand and Malaysia bidirectional causality was observed. Also, they reached a conclusion that stock prices are negatively related to the exchange rate in the selected nations except Thailand.

Okuyan \& Erbaykal (2008) analyzed stock return and exchange rates relationship for 13 emerging countries, and employed different time interval for each nation. The outcomes provided evidence for eight economies' causality relationships. There was also no causality in Turkey between these financial variables.

Kandir (2008) examined the effects of macroeconomic indicators on stock returns from July 1997 to June 2005 by using OLS estimation in Turkey. The study showed that the exchange rates have a significant and positive relationship with stock returns.

\section{Research Methodology}

In the study, Johansen Cointegration Test and Granger causality test were applied to the series to examine the relationship between the variables. To reveal the real relationships between the variables the series should be stationary. Also, to apply the Johansen co-integration test, the time series to be used must be stationary at the same level. Therefore, by applying unit root tests to the series, the series should be stationary at the same level (Granger \& Clive, 1969). If the series is not stationary at the same level, the cointegration test cannot be applied to the series (Granger, 1974). Usually, the series becomes stationary by taking the first or second differences of the time series (Bozkurt, 2007). Augmented Dickey-Fuller (ADF) test is the most commonly used test when investigating whether the series is stationary or not. So, we used the ADF test to investigate whether the variables stationary or not. If the variables are stationary in the first differences, it is necessary to determine whether the variables are cointegrated or not. The existence of a cointegration relationship between the variables 
means that there is a long-term relationship between the variables. For this purpose, the Johansen co-integration test (1988) was used. The existence of cointegration means that there is causality in at least one direction between the two variables (Syzdykova, 2016). And finally, Granger Causality in Vector Autoregression Framework should be applied to analyze the causality between variables. After that, we can reach that, the direction of the relationship between the variables.

\subsection{Data and Variables}

In the study, three variables which are Dow Jones Industrial Average, USD/EUR exchange rate, and USD/CHF exchange rate used as data, which are provided from the data distribution system on the website of FRED Economic Data. Euro and Swiss Franc were selected as exchange rates to make empirical analysis. Also the data used in this paper consists of monthly indexes of Dow Jones Industrial Average and monthly exchange rates between November 1999 to August 2008 and September 2008 to November 2019 separately. You can find the details of data at the table (1) below.

Table 1: Variables

\begin{tabular}{llll}
\hline Variables & Explanations & Unit & Data Source \\
\hline DJI & Dow Jones Industrial Average & Index & S\&P Dow Jones Indices LLC \\
USD/EUR & Euro $(€)$ against to one U.S. Dollars $(\$)$ & Index & $\begin{array}{l}\text { Board of Governors of the Federal Reserve } \\
\text { System }\end{array}$ \\
USD/CHF & Swiss Franc (fr.) against to one U.S. Dollars (\$) & Index & $\begin{array}{l}\text { Board of Governors of the Federal Reserve } \\
\text { System }\end{array}$ \\
\hline
\end{tabular}

The study was selected these time periods one by one because the aim to investigate the relationship between stock index and exchange rates before and after global financial crises especially in the United States. In 15 September 2008, one of the biggest investment bank of the United States, Lehman Brothers was collapsed. Therefore, the study took this catastrophe as a milestone regarding time interval. This crisis affected to the both economically and financially the global markets, in a way, has changed everything we know regarding finance and economics. EViews 10 statistical package program is used to test Granger causality and investigate the relationship between these variables.

\section{Findings}

First of all, unit root test was applied to the variables. When the ADF unit root test is applied to the dependent and independent variables, it is concluded that these series have unit root or are not stationary before and after the collapse of Lehman Brothers. You can find the results in Table (2). Our hypothesis would be conducted for each variable as follows for the ADF statistics:

$\mathrm{H}_{0}$ : There is a unit root at level.

$\mathrm{H}_{1}$ : There is no unit root at level. 
Table 2: ADF Unit Root Test Results, at level, trend

\begin{tabular}{llll}
\hline Variable & p-value & Null Hypothesis & Results \\
\hline BEFORE_DJI & 0.48 & Fail to Reject & Variable is non-stationary \\
BEFORE_USD/EUR & 0.91 & Fail to Reject & Variable is non-stationary \\
BEFORE_USD/CHF & 0.78 & Fail to Reject & Variable is non-stationary \\
AFTER_DJI & 0.98 & Fail to Reject & Variable is non-stationary \\
AFTER_USD/EUR & 0.63 & Fail to Reject & Variable is non-stationary \\
AFTER_USD/CHF & 0.08 & Fail to Reject & Variable is non-stationary \\
\hline
\end{tabular}

${ }^{*}$ significant at $1 \%{ }^{*}$ significant at $5 \%$

Therefore, we should use differences for the variables to make data stationary. As it can be seen in Table (3), all variables are stationary (at 1 per cent) in the first differences before and after the collapse of Lehman Brothers.

Table 3: ADF Unit Root Test Results, at 1st difference, trend

\begin{tabular}{llll}
\hline Variable & p-value & Null Hypothesis & Results and Order of Integration \\
\hline BEFORE_DJI & $0,000^{*}$ & Reject & Variable is stationary I(1) \\
BEFORE_USD/EUR & $0,000^{*}$ & Reject & Variable is stationary I (1) \\
BEFORE_USD/CHF & $0,000^{*}$ & Reject & Variable is stationary I (1) \\
AFTER_DJI & $0,000^{*}$ & Reject & Variable is stationary I $(1)$ \\
AFTER_USD/EUR & $0,000^{*}$ & Reject & Variable is stationary I(1) \\
AFTER_USD/CHF & $0,000^{*}$ & Reject & Variable is stationary I(1) \\
\hline
\end{tabular}

${ }^{*}$ significant at $1 \%{ }^{*}$ significant at $5 \%$

It is necessary to determine how many lag lengths are used in the system equation before applying the cointegration test. The following table shows that the lag length criteria selection before the collapse.

Table 4: Determine the lag length criteria (Before the Collapse)

\begin{tabular}{lllllll}
\hline Lag & LogL & LR & FPE & AIC & SC & HQ \\
\hline 0 & -588.36 & NA & 51.21 & 12.45 & 12.53 & 12.48 \\
1 & -207.55 & 729.55 & 0.02 & 4.62 & $4.95^{*}$ & $4.75^{*}$ \\
2 & -195.67 & 22.00 & 0.02 & 4.56 & 5.13 & 4.79 \\
3 & -187.34 & 14.92 & 0.02 & 4.58 & 5.38 & 4.90 \\
4 & -179.76 & 13.07 & 0.02 & 4.60 & 5.65 & 5.03 \\
5 & -169.19 & 17.59 & 0.02 & 4.57 & 5.86 & 5.09 \\
6 & -158.22 & 17.56 & $0.02^{*}$ & $4.53^{*}$ & 6.06 & 5.15 \\
7 & -155.23 & 4.59 & 0.02 & 4.66 & 6.43 & 5.37 \\
8 & -153.58 & 2.43 & 0.03 & 4.81 & 6.83 & 5.63 \\
9 & -151.16 & 3.42 & 0.03 & 4.95 & 7.21 & 5.86 \\
10 & -138.43 & $17.16^{*}$ & 0.03 & 4.87 & 7.37 & 5.88 \\
11 & -135.33 & 3.97 & 0.03 & 5.00 & 7.74 & 6.10 \\
12 & -129.76 & 6.80 & 0.04 & 5.07 & 8.05 & 6.27 \\
\hline
\end{tabular}

FPE: Final Prediction Error, AIC: Akaike information criteria, SC: Schwarz-Information Criteria, HQ: Hannan-Quinn 
When the results in Table 4 are considered, it is seen that the Hannan-Quinn and SchwarzInformation Criteria give the first leg length. Akaike information criteria give the sixth lag length in the results. Therefore, we selected the first lag length before we apply the Johansen co-integration test for before the collapse.

The following table 5 shows that the lag length criteria selection after the collapse.

Table 5: Determine the Lag Length Criteria (After the Collapse)

\begin{tabular}{lllllll}
\hline Lag & LogL & LR & FPE & AIC & SC & HQ \\
\hline 0 & -835.64 & NA & 187.64 & 13.75 & 13.82 & 13.78 \\
1 & -278.94 & 1076.90 & 0.02 & 4.77 & $5.05^{*}$ & $4.88^{*}$ \\
2 & -266.91 & $22.67^{*}$ & $0.02^{*}$ & $4.72^{\star}$ & 5.20 & 4.91 \\
3 & -263.03 & 7.13 & 0.03 & 4.80 & 5.49 & 5.08 \\
4 & -256.22 & 12.16 & 0.03 & 4.84 & 5.74 & 5.20 \\
5 & -247.31 & 15.49 & 0.03 & 4.84 & 5.94 & 5.29 \\
6 & -239.46 & 13.26 & 0.03 & 4.86 & 6.17 & 5.39 \\
7 & -229.32 & 16.61 & 0.03 & 4.84 & 6.36 & 5.46 \\
8 & -225.58 & 5.96 & 0.03 & 4.93 & 6.65 & 5.63 \\
9 & -223.04 & 3.91 & 0.03 & 5.03 & 6.96 & 5.82 \\
10 & -218.90 & 6.19 & 0.04 & 5.11 & 7.25 & 5.98 \\
11 & -214.71 & 6.04 & 0.04 & 5.19 & 7.54 & 6.14 \\
12 & -210.78 & 5.47 & 0.04 & 5.28 & 7.83 & 6.31 \\
\hline
\end{tabular}

FPE: Final Prediction Error, AIC: Akaike information criteria, SC: Schwarz-Information Criteria, HQ: Hannan-Quinn

When the results in the table above are considered, it is seen that the Akaike information criteria and Final Prediction Error give the second leg length. Therefore, we selected the second lag length before we apply the Johansen co-integration test for after the collapse.

For the co-integration test, if the series is not stationary at the level values but is stationary in the first difference then the prerequisite for the implementation of the Johansen test will be provided. According to $\mathrm{ADF}$ unit root test result, all variables became stationary in the first difference. Johansen co-integration test will show whether there are co-integrated vectors between variables or not.

Table 6 shows the trace and maximum eigenvalue statistics results before the collapse, while Table 7 shows the results after the collapse. To understand the test results, we should conduct the hypothesis.

$\mathrm{H}_{0}$ : There is no co-integrated vector.

$\mathrm{H}_{1}$ : There is at most one co-integrated vector.

$\mathrm{H}_{2}$ : There is at most two co-integrated vectors. 
Table 6: Johansen Co-Integration Test Results (Before the Collapse)

\begin{tabular}{lllll}
\hline $\begin{array}{l}\text { Hypothesized No. Of } \\
\text { CE(s) }\end{array}$ & Eigenvalue & Trace Statistic & $\mathbf{0 . 0 5}$ Critical Value & Prob. ${ }^{* *}$ \\
\hline None & 0.12 & 17.85 & 29.80 & 0.58 \\
At most 1 & 0.04 & 4.68 & 15.50 & 0.84 \\
At most 2 & 0.00 & 0.39 & 3.84 & 0.53 \\
\hline
\end{tabular}

Table 7: Johansen Co-Integration Test Results (After the Collapse)

\begin{tabular}{lllll}
\hline $\begin{array}{l}\text { Hypothesized No. Of } \\
\text { CE(s) }\end{array}$ & Eigenvalue & Trace Statistic & $\mathbf{0 . 0 5}$ Critical Value & Prob. $^{* *}$ \\
\hline None & 0.07 & 15.33 & 29.80 & 0.76 \\
At most 1 & 0.04 & 5.93 & 15.50 & 0.70 \\
At most 2 & 0.00 & 0.15 & 3.84 & 0.70 \\
\hline
\end{tabular}

For the all hypotheses in the table, trace and maximum Eigen statistics are lower than the critical value. So, the all hypotheses cannot be rejected. According to the results, there is no co-integration between the variables before and after the crisis. Therefore, VAR Granger causality test will be applied.

Table 8: Granger Causality Test Results (Before the Collapse)

\begin{tabular}{lllc}
\hline Dependent variable: BEFORE_USD/EUR & & & \\
\hline Excluded & Chi-sq & df & Prob. \\
BEFORE_USD/CHF & 6.76 & 2 & 0.03 \\
BEFORE_DJI & 5.88 & 2 & 0.05 \\
All & 7.07 & 4 & 0.13 \\
\hline Dependent variable: BEFORE_USD/CHF & & & \\
\hline Excluded & Chi-sq & df & Prob. \\
BEFORE_USD/EUR & 2.212 & 2 & 0.33 \\
BEFORE_DJI & 2.88 & 2 & 0.24 \\
All & 3.16 & 4 & 0.53 \\
\hline Dependent variable: BEFORE_DJI & & & \\
\hline Excluded & Chi-sq & df & Prob. \\
BEFORE_USD/EUR & 2.767 & 2 & 0.25 \\
BEFORE_USD/CHF & 3.00 & 2 & 0.22 \\
All & 4.82 & 4 & 0.30 \\
\hline
\end{tabular}

Table 9: Granger Causality Test Results (After the Collapse)

\begin{tabular}{lllc}
\hline Dependent variable: AFTER_DJI & & & \\
\hline Excluded & Chi-sq & df & Prob. \\
AFTER_USD/CHF & 0.963519 & 2 & 0.6177 \\
AFTER_USD/EUR & 0.404423 & 2 & 0.8169 \\
All & 1.407878 & 4 & 0.8428 \\
\hline Dependent variable: AFTER_USD/CHF & & & \\
\hline Excluded & Chi-sq & df & Prob. \\
AFTER_DJI & 0.432297 & 2 & 0.8056
\end{tabular}




\begin{tabular}{lllc} 
AFTER_USD/EUR & & & \\
All & 0.068663 & 2 & 0.9663 \\
\hline Dependent variable: AFTER_USD/EUR & 0.653488 & 4 & 0.9569 \\
\hline Excluded & & & \\
AFTER_DJI & Chi-sq & df & Prob. \\
AFTER_USD/CHF & 2.015294 & 2 & 0.3651 \\
All & 2.901150 & 2 & 0.2344 \\
\hline
\end{tabular}

In the tables at above ( 8 and 9), we can see the probability results of variables at $\% 5$ significance level before and after the collapse. If we write the hypothesis US Dollar / Euro rate is dependent variable:

$\mathrm{H}_{0}: \mathrm{DJI}$ is not the granger cause of USD/EUR

$\mathrm{H}_{1}$ : DJI is the granger cause of USD/EUR

$\mathrm{H}_{0}: \mathrm{USD} / \mathrm{CHF}$ is not the granger cause of USD/EUR

$\mathrm{H}_{1}: \mathrm{USD} / \mathrm{CHF}$ is the granger cause of USD/EUR

These are the hypothesis we should use if the US Dollar / Euro rate is the dependent variable in the equation. In the results, both Dollar / Swiss Franc rate and Dow Jones independent variables' probability is less than 5 per cent so we can reject the null hypothesis and accept the alternative hypothesis before the crisis. So, we can say that USD/CHF and Dow Jones Industrial Average are the granger cause of the USD/EUR before the crisis. However, p-value results show that we cannot reject null hypothesis after the crisis.

Secondly, we should make the hypothesis if US Dollar / Swiss Franc rate is the dependent variable.

$\mathrm{H}_{0}: \mathrm{DJI}$ is not the granger cause of USD/CHF

$\mathrm{H}_{1}$ : DJI is the granger cause of USD/CHF

$\mathrm{H}_{0}: \mathrm{USD} / \mathrm{EUR}$ is not the granger cause of USD/CHF

$\mathrm{H}_{1}: \mathrm{USD} / \mathrm{EUR}$ is the granger cause of USD/CHF

In the table, results show that both USD/EUR and DJI probabilities are more than 10 per cent before and after the crisis. So we cannot reject the null hypothesis. There is no granger causality relationship. Lastly, we design the hypothesis if Dow Jones Industrial Average is the dependent variable in the equation.

$\mathrm{H}_{0}$ : USD/CHF is not the granger cause of DJI

$\mathrm{H}_{1}: \mathrm{USD} / \mathrm{CHF}$ is the granger cause of DJI

$\mathrm{H}_{0}$ : USD/EUR is not the granger cause of DJI 
$\mathrm{H}_{1}$ : USD/EUR is the granger cause of DJI

In this equation, USD/EUR and USD/CHF are not the granger cause of DJI because the probability is higher than 10 percent so we should accept the null hypothesis and reject the alternative hypothesis.

\section{Conclusion and Discussion}

In this study, the causality relationship between stock prices and exchange rates in the United States before and after the 2008 financial crisis was investigated. In other words, we tried to examine if a change in stock prices affects the exchange rate or if a change in the exchange rate causes a change in stock prices before and after the finance crisis in the United States. In order to discover this relationship, we investigated the Granger causality between stock index and exchange rates in the United States. Regarding the analysis, Granger test results show us that Dow Jones Industrial Average and USD/CHF were the Granger cause of USD/EUR exchange rates before the collapse of Lehman Brothers. This means that there was a one-way causality from USD/CHF and Dow Jones Index to USD/EUR before the financial crisis. However, after the collapse of Lehman Brothers results have changed and we reached that there is no relationship between these variables and all of causality situations disappear. Furthermore, there is no causality between other variables before and after the collapse. This result is in line with the results of similar studies conducted in developed countries.

\section{Author Contribution}

\begin{tabular}{|l|l|l|}
\hline CONTRIBUTION RATE & EXPLANATION & CONTRIBUTORS \\
\hline Idea or Notion & Form the research idea or hypothesis & $\begin{array}{l}\text { Oğuzhan ERCAN } \\
\text { Jale S. ORAN }\end{array}$ \\
\hline Literature Review & Review the literature required for the study & Oğuzhan ERCAN \\
\hline Research Design & $\begin{array}{l}\text { Designing method, scale, and pattern for the } \\
\text { study }\end{array}$ & Oğuzhan ERCAN \\
\hline Data Collecting and Processing & Collecting, organizing, and reporting data & Oğuzhan ERCAN \\
\hline Discussion and Interpretation & $\begin{array}{l}\text { Taking responsibility in evaluating and finalizing } \\
\text { the findings }\end{array}$ & $\begin{array}{l}\text { Oğuzhan ERCAN } \\
\text { Jale S. ORAN }\end{array}$ \\
\hline
\end{tabular}

\section{Conflict of Interest}

The authors declared no potential conflicts of interest.

\section{Financial Support}

The authors have not received any financial support for this study 


\section{References}

Aggarwal, R. (1981). Exchange rates and stock prices: A study of U.S. capital market under floating exchange rates. Akron Bussiness and Economic Review, 12(3), 7-12.

Ajayi, R. A. \& Mougoue, M. (1996). On the dynamic relation between stock prices and Exchange rates. Journal of Financial Research, 19,193-207.

Ajayi, R. A., Friedman, J., \& Mehdian, S. M., (1998). On the relationship between stock returns and exchange rates: Test of granger causality. Global Finance Journal, 9 (2), 241-251.

Bozkurt, H. (2007). Zaman serileri analizi, Bursa: Ekin Kitabevi.

Doong, S., Yang, S. \& Wang, A. T. (2005). The dynamic relationship and pricing of stocks and exchange rates: Empirical evidence from asian emerging markets. Journal of American Academy of Business, Cambridge, 7(1), 118-123.

Erbaykal, E. \& Okuyan, H. A. (2007). Hisse senedi fiyatları ile döviz kuru ilişkisi: Gelişmekte olan ülkeler üzerine ampirik bir uygulama. BDDK Bankacılık ve Finansal Piyasalar Dergisi, 1(1), 77-89.

Granger, C. W. J. (1969). Investigating causal relations by econometric models and cross-spectral methods. Econometrica: Journal of the Econometric Society, 37(3), 424-438.

Granger, C. W. J. \& Newbold, P. (1974). Spurious regression in econometrics. Journal of Econometrics, 2, 111120.

Granger, C. W. J., Huang, B \& Yang, C. (2000). A bivariate causality between stock prices and exchange rates: Evidence from recent asian flu. The Quarterly Review of Economics and Finance, 40, 337 -354.

Inci, A. C. \& Lee, B. S. (2014). Dynamic relations between stock returns and exchange rate changes. European Financial Management, 20, 71-106

Johansen S. (1988). Statistical analysis of cointegration vectors. Journal of Economic Dynamics and Control, 12, 2-3, 231-254.

Kandir, S. Y. (2008). Macroeconomic variables, firm characteristics and stock returns: Evidence from Turkey. International Research Journal of Finance and Economics Issue, 16, 35 - 45

Kim, K. (2003). Dollar exchange rate and stock price: Evidence from multivariate cointegration and error correction model. Review of Financial Economics, 12, 301-313.

Muhammad, N. \& Rasheed, A. (2002). Stock prices and exchange rates: Are they related? Evidence from south asian countries. The Pakistan Development Review, 41(4), 535-550.

Nieh, C. \& Lee, C. (2001). Dynamic relationship between stock prices and exchange rates for G-7 countries. The Quarterly Review of Economics and Finance, 41, 477-490.

Stavarek, D. (2005). Stock prices and exchange rates in the EU and the USA: Evidence of their mutual interactions. Journal of Economics and Finance, vol. 55(3-4), 141-161.

Syzdykova, A. (2016). Döviz kuru ve enflasyon arasındaki ilişki: BRİC ülkeleri örneği. Uluslararası Yönetim ve Sosyal Araştırmalar Dergisi, 3(6), 1-14.

Vygodina, A. V. (2006). Effects of size and international exposure of the US firms on the relationshipb e twe en stock prices and exchange rates. Global Finance Journal 17, 214-223.

\section{Resume}

Oğuzhan Ercan is Ph.D. candidate in Accounting and Finance Department, Social Sciences Institute, Marmara University. He completed his undergraduate in Faculty of Business Administration from Marmara University in 2016. He completed his master's degree in International Business Economics 
at University of Sussex in 2017. His research interests focus on the areas of international economics, international finance, and corporate finance.

Jale Oran (Prof. Dr.) is professor of finance, and teaching finance courses in Business Administration Program in English language, Marmara University. She has B.A. and M.A. degrees from Boğaziçi University and Ph.D. from Marmara University. She has professor position since 2010. Her research interests are in the fields of behavioural finance, corporate finance and auctions. 